\title{
銅層形成誘電体基板のマイクロ波・ミリ波評価
}

\author{
小林 禧夫*
}

\section{Microwave and Millimeter-Wave Evaluation of Copper-Clad Dielectric Substrates}

\author{
Yoshio KOBAYASHI*
}

*サムテック有限会社（† 338-0003＼cjkstart埼玉県さいたま市中央区本町東 1-6-1 大野ビル 201）

* SUMTEC, Inc. (Ohno Bldg. 2F, 1-6-1 Hommachi-Higashi, Chuo-ku, Saitama City, Saitama 338-0003)

\section{1. はじめに}

近年, 情報機器の動作速度は高速化してギガビット領域 に入り，また無線通信機器も高周波化してマイクロ波・ミ リ波領域に入り, 高周波数帯における低損失誘電体基板材 料の開発が盛んになっている。さらに多品種少量生産時代 の到来とともに，ますます情報機器の開発期間が短くな り, 試作回数の減少を目的とした電子回路の高精度・短期 間設計の実現が望まれている。

最近, 誘電体基板の正確な材料定数の測定結果を用いた 電磁界解析ソフトの計算によりマイクロストリップ線路や フィルタの高精度設計が可能になることを示した ${ }^{1), 2) 。 ま ~}$ た，筆者らは設計に必要な誘電体材料の高精度測定法を 種々開発し 3) 11)，マイクロ波・ミリ波帯にわたり種々の基 板材料を評価してきた。この結果, 低損失材としてょく用 いられてきたポリテトラフルオロエチレン (PTFE)には $23^{\circ} \mathrm{C}$ 付近に相転移による比誘電率の急激な変化があることがわ

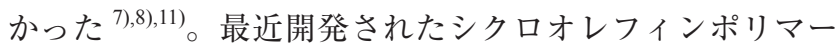
$(\mathrm{COP})^{12)}$ は, PTFE と同程度の低誘電率低損失でありながら 比誘電率の温度変化が緩やかなため電子回路基板として有 望である。しかしガラス転移温度が $160^{\circ} \mathrm{C}$ 付近にあり，は んだ付が困難なため応用は限られるかもしれない。一方, 液晶ポリマー (LCP) はマイクロ波・ミリ波回路用低損失材

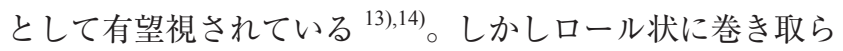
れた LCP フィルムは比誘電率に面内異方性があることがわ

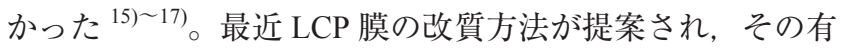
効性が実証された ${ }^{18)}$ 。

本論文では，有機材料を用いて構成されるいくつかの基 板について, 共振法による周波数依存性および温度依存性 の測定方法および測定結果について紹介する。

\section{2. 材料評価に用いた測定方法 ${ }^{3) \sim 10)}$}

電子回路基板として図 1 に示す銅層形成誘電体積層基板 がよく用いられる。この回路設計を高精度に行うには，基 板の垂直方向の比誘電率 $\varepsilon_{r n}$ と誘電正接 $\tan \delta_{n}$ および平面方
向の $\varepsilon_{r t}, \tan \delta_{t}$ に加えて, 基板表面に形成された銅䇴の表面 比導電率 $\sigma_{r f}$ および界面比導電率 $\sigma_{r b}$ に関する測定值が必要 とされる ${ }^{1), 2)}$ 。これらの材料定数の測定には, 高精度測定法

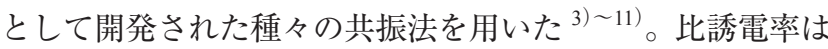
共振器の共振周波数の測定值から, また誘電正接 $\tan \delta$ およ び比導電率は共振器の性能指数 Q の測定值から, 電磁界解 析に基ついた計算から求められる。測定精度は比誘電率測 定に関して $1 \sim 2 \%$ ，誘電正接測定に関して $10 \sim 30 \%$ ，比導 電率測定に関して $3 \%$ 程度である。以下に測定法の概要を 述べる ${ }^{3) \sim 11) 。 ~}$

\section{(1) $\varepsilon_{r n}$ と $\tan \delta_{n}$ の測定方法}

本測定には図 2 に示す同軸励振平衡形円板共振器を用い た。この共振器は, 高次 $\mathrm{TM}_{0 \mathrm{~m} 0}$ モードを用いることにより 6〜 $110 \mathrm{GHz}$ にわたる周波数依存性の測定が可能であり，ま た銅板からの試料の熱伝導が良好なため温度依存性の正確 な測定にも有効である。

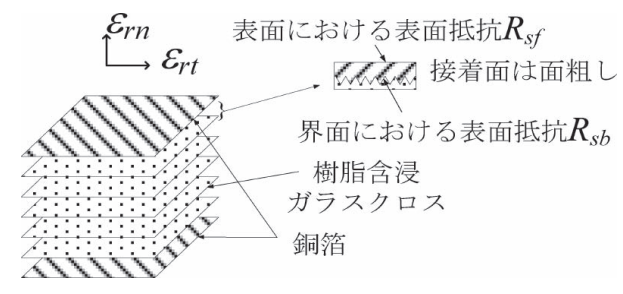

図 1. 銅形成誘電体積層基板の構造図

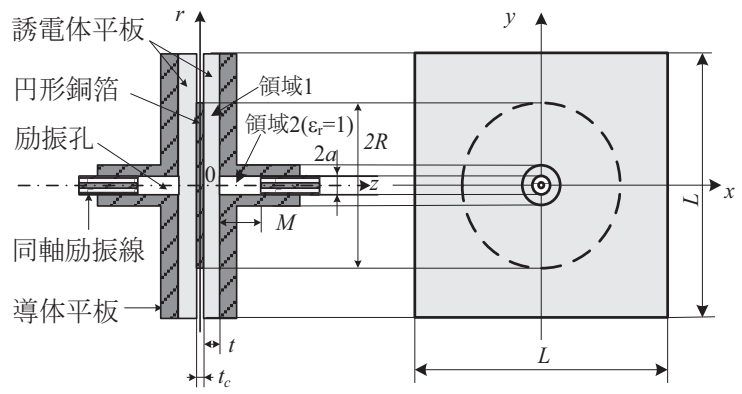

図 2. 同軸励振平衡形円板共振器 


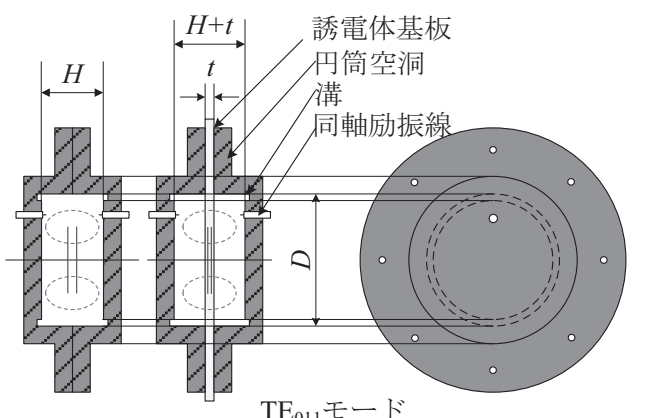

(a)

(b)

図 3. 円筒空洞共振器の構造

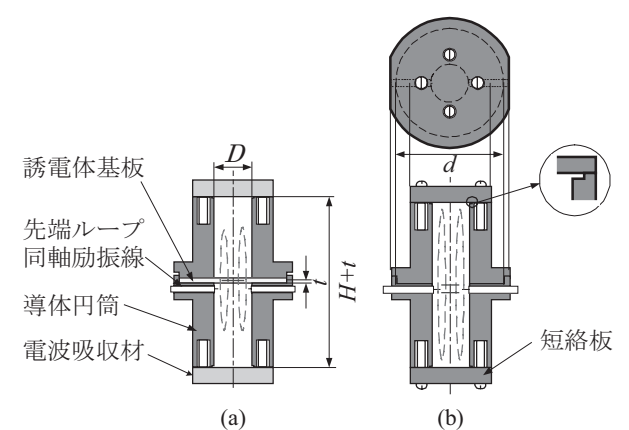

図 4. 遮断円筒導波管の構造

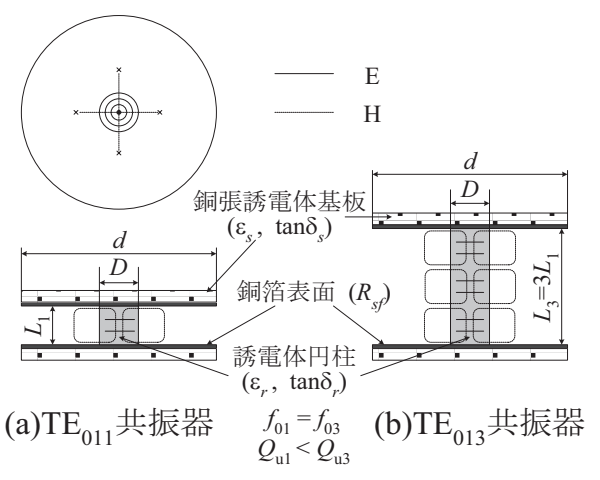

図 5. 両端短絡形誘電体円柱共振器の構造

(2) $\varepsilon_{r t}$ と $\tan \delta_{t}$ の測定方法

本測定には, 図 3 に示す空洞共振器法 $(6 \sim 30 \mathrm{GHz})$ 打 よび図 4 に示す遮断円筒導波管法（30〜80 GHz）を用い た。周波数依存性測定には寸法の異なる複数の共振器を用 いた。温度依存性の測定には平面試料への熱伝導時間を十 分に考慮して行なった。

(3) $\sigma_{r f}$ と $\sigma_{r b}$ の測定方法

$\sigma_{r f}$ の測定には図 5 に示す 2 個の両端短絡形誘電体円柱共 振器を用いた。まず両共振器の $\mathrm{Q}$ 值の測定結果から銅簿の 表面抵抗 $R_{s f}$ を求め, さらに計算により $\sigma_{r f}$ の值を求める。 $\sigma_{r b}$ の測定は, 同様の誘電体共振器を用いて行った ${ }^{7), 8)}$ 。周 波数依存性の測定には複数の誘電体共振器を用いて行う必 要がある。

\section{3. 測定結果}

\section{1 ガラスクロス・エポキシ樹脂積層基板 (FR-4)}

2 種類の FR-4 基板（R-1766：パナソニック, ELC-4765： 住友ベークライト）について, 比誘電率と誘電正接の周波

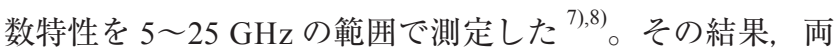
基板の比誘電率には周波数依存性はなく, R-1766 では $\varepsilon_{r n}=$ $4.01, \varepsilon_{r t}=4.43$ ，また ELC-4765 では $\varepsilon_{r n}=4.22, \varepsilon_{r t}=4.55 て ゙$ あった。さらに $\tan \delta_{n}$ と $\tan \delta_{t}$ は両基板で異なり，また周波 数とともに $0.015 \sim 0.25$ の間で直線的に上昇する傾向が見ら れた。このように FR-4 基板特性は材料供給メーカにより 特性が異なるので，使用する基板ごとに測定する必要があ る。

\subsection{PTFE 基板}

比誘電率と誘電正接の周波数特性を 7 $76 \mathrm{GHz}$ の範囲で 測定した ${ }^{8)}$ 。その結果, $\varepsilon_{r n}=\varepsilon_{r t}=2.05$ であり，比誘電率に 周波数依存性は見られなかった。 $\tan \delta_{n}=\tan \delta_{t}$ は周波数の 増加に伴い，0.0002 0.0004の間で直線的に上昇する結果 となった。また, $\varepsilon_{\mathrm{rn}}$ と $\tan \delta_{n}$ の温度特性を $-40 \sim 80^{\circ} \mathrm{C}$ の範 囲で測定した結果, $23^{\circ} \mathrm{C}$ 付近において急激に変化すること が明らかとなった ${ }^{8), 11)}$ 。

\section{3 ガラスクロス PTFE 積層基板 (CGA500：中興化成)}

比誘電率と誘電正接の周波数特性を $6 \sim 60 \mathrm{GHz}$ の範囲で 測定した ${ }^{8)}$ 。その結果, $\varepsilon_{r n}=3.1, \quad \varepsilon_{r t}=3.7$ であり, 比誘電 率に周波数依存性は見られなかった。 $\tan \delta_{n}$ は周波数の増加 に伴い，0.002 0.004の間で直線的に増加した。また, $\tan \delta_{t}$ は，6〜40 GHzに押いて周波数の増加に伴い，0.0038〜 0.007 で直線的に増加した。平衡形円板共振器の $\mathrm{TM}_{010}$ モー ドを用いた同一基板の温度依存性の測定結果 ${ }^{20)}$ を図 6 に示 す。共振周波数 $f_{0}$ の温度依存性の測定結果より $\varepsilon_{r n}$ の温度 依存性を求め, 無負荷 $\mathrm{Q}, Q_{u}$ の温度依存性の測定結果より $\tan \delta_{n}$ の温度依存性を求めた。各特性において $23^{\circ} \mathrm{C}$ 付近で みられる大きな変化は, PTFEの影響によるものである。
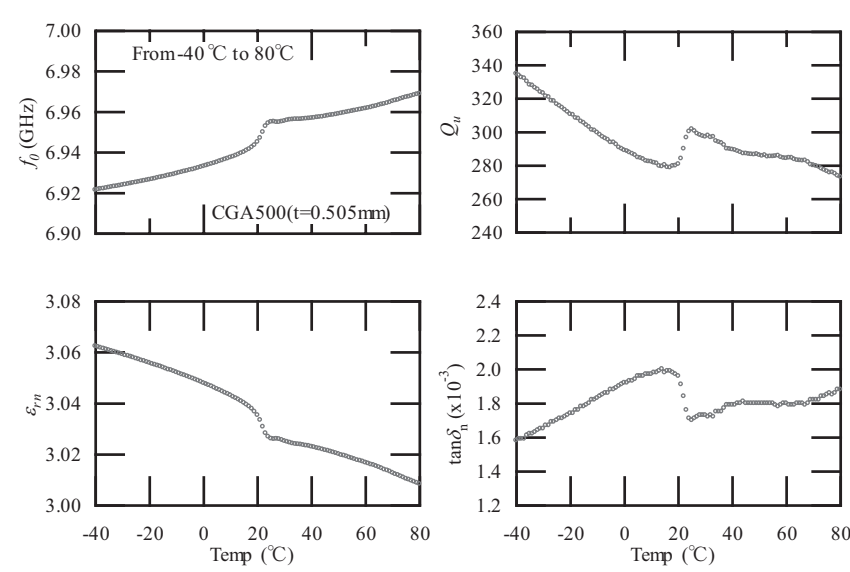

図 6. ガラスクロス PTFE 基板の温度依存性測定 (CGA500) 


\subsection{COP 基板 (ZF16：日本ゼオン) ${ }^{19)}$}

測定に用いた COP 基板 (ZF16) は, 無色透明で固く, 厚 さの均一性はマイクロメータの測定により $1 \mu \mathrm{m}$ 以内のば らつきに抑えられていた。円形銅䇴直径 $15 \mathrm{~mm}$ の平衡形円 板共振器を用いたときの厚さ $\mathrm{t}=0.378 \mathrm{~mm}$, 面積 $50 \mathrm{~mm} \times$ $50 \mathrm{~mm}$ の平板試料の周波数応答波形を図 7 に示す ${ }^{19)}$ 。10 $110 \mathrm{GHz}$ にわたり 8 個の $\mathrm{TM}_{0 \mathrm{~m} 0}(\mathrm{~m}=1 \sim 8)$ モードの共振 波形が観測されている。各モードの測定值から求めた $\varepsilon_{r n}$ お よび $\tan \delta_{n}$ を図 8 に示す。同図には複数の空洞共振器と遮 断円筒導波管を用いて測定した $\varepsilon_{r t}$ および $\tan \delta_{t}$ の測定結果 も示す ${ }^{19)}$ 。これより, ZF16 試料は $\varepsilon_{r n}=\varepsilon_{r t}=2.35$ で周波数 依存性のない等方性材料であることがわかった。また $\tan \delta_{t}=\tan \delta_{n}=0.0002 \sim 0.0006$ の間で周波数と共に直線的に 上昇する傾向を示した。さらに $\mathrm{TM}_{010}$ モードを用いて共振 周波数および無負荷 $\mathrm{Q}, Q u$ の温度依存性の測定結果から $\varepsilon_{r n}$ および $\tan \delta_{n}$ の温度依存性を求めた。 $-40 \sim 80^{\circ} \mathrm{C}$ にわたる測 定結果を図 9 に示す ${ }^{20)}$ 。測定值 $f_{0}$ から $\varepsilon_{r n}$ を求める際, $\mathrm{ZF} 16$ 試料の線膨張係数 $\tau_{\mathrm{c}}=70 \mathrm{ppm} /{ }^{\circ} \mathrm{C}$ および銅箔直径の線 膨張係数 $16.8 \mathrm{ppm} /{ }^{\circ} \mathrm{C}$ を考慮して計算した。また測定值 $Q u$ から $\tan \delta_{n}$ を求める際, 銅箔導電率の熱抵抗係数 $C_{f}=0.00393$

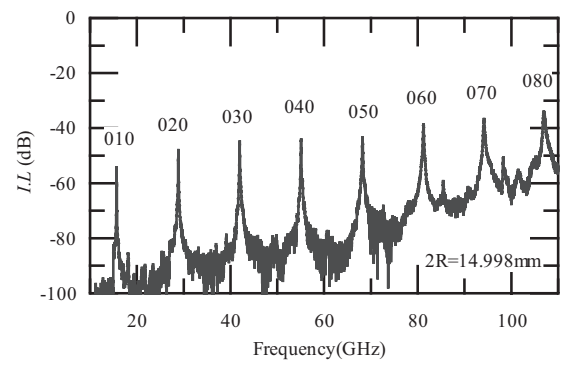

図 7. COP 基板 (ZF16) の周波数応答波形
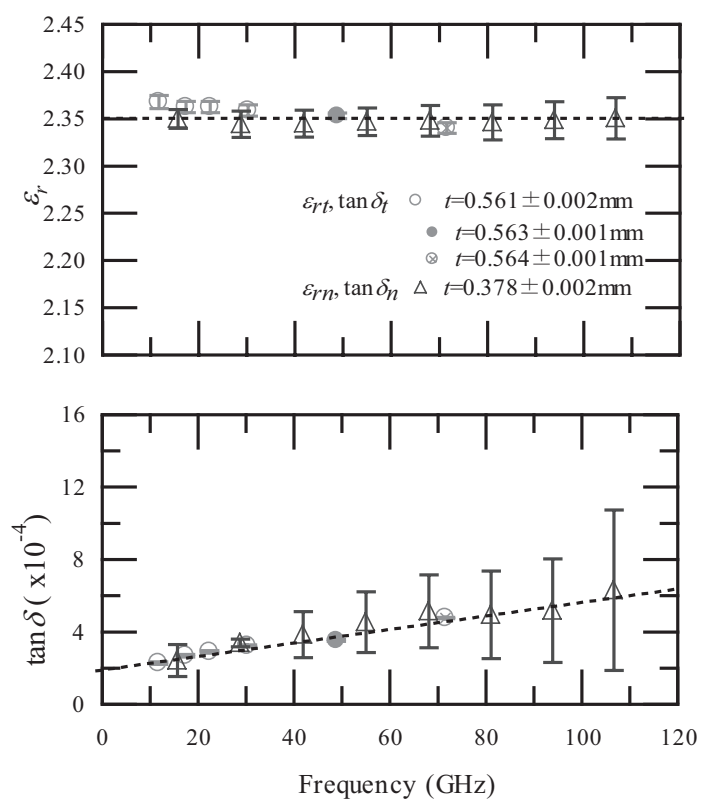

図 8. COP 基板 (ZF16) の複素比誘電率測定結果
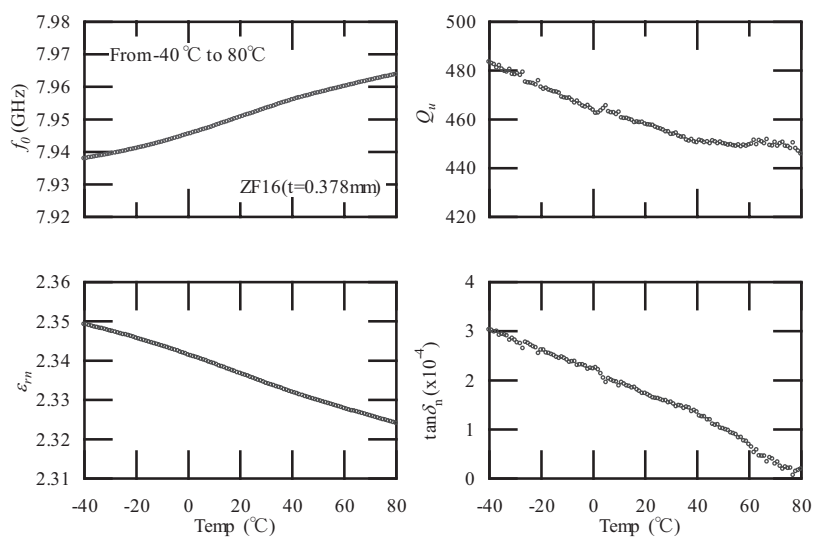

図 9. COP 基板 (ZF-16) の温度依存性の測定結果

を考慮して計算した。これより $Q_{u}$ 值が温度上昇と共に減 少するにも関わらず，導体損の増加が大きいため $\tan \delta_{n}$ は 温度と共に減少する結果となった。

以上より COP 材は低誘電率低損失に加えて, PTFEのよ うに $23^{\circ} \mathrm{C}$ 付近における急激な特性変化もないので, 種々 の測定法を比較する際の標準試料として有望であると結論 される。

\subsection{LCP 基板 (CT-Z : クラレ)}

初期の LCP 基板は高分子の配向性が強く，図 10 に示す ように, $\mathrm{z}$ 方向の $\varepsilon_{r n}$ に加えて面内でも $\mathrm{x}$ 方向と $\mathrm{y}$ 方向で比 誘電率 $\left(\varepsilon_{x}, \varepsilon_{y}\right)$ が異なる面内異方性をもつものであっ た ${ }^{15) \sim 17)}$ 。図 3 に示す円形空洞共振器には直交する $\mathrm{TE}_{111}$ モードが存在する。この共振モードの共振周波数が $\mathrm{x}$ 方向 と $\mathrm{y}$ 方向で異なることを利用して $\varepsilon_{x}$ と $\varepsilon_{y}$ を分離測定する方

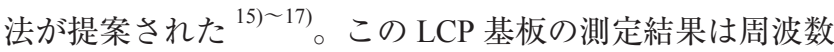
依存性なく $\varepsilon_{r n}=2.72, \varepsilon_{x}=3.6, \varepsilon_{y}=3.3$ であり, $\mathrm{x}$ 方向と $\mathrm{y}$ 方 向で約 $10 \%$ の比誘電率差があった ${ }^{15), 16)}$ 。この面内異方性は 電子回路の設計を困難にするため, 望ましくない特性であ る。面内異方性の原因が基板の $\mathrm{x}$ 方向と $\mathrm{y}$ 方向の線膨張係 数の差に関係することに着目して, $\mathrm{x}$ 方向と $\mathrm{y}$ 方向で同じ 比誘電率を持つようにLCP 膜の改質が行われた ${ }^{18)}$ 。この改 質 LCP フィルム $(\mathrm{CT}-\mathrm{Z})$ の測定結果を図 11 に示す ${ }^{17)}$ 。これ より 6〜25 GHzにわたり面内異方性がなく周波数依存性の ない $\varepsilon_{r n}=2.87, \varepsilon_{x}=\varepsilon_{y}=3.35$ の CT-Z 膜が開発された。また 遮断円筒導波管法を用いて CT-Z フィルムと共により密度 の高い CT-F に関する $\varepsilon_{r n}$ と $\tan \delta_{n}$ の温度依存性の測定結果
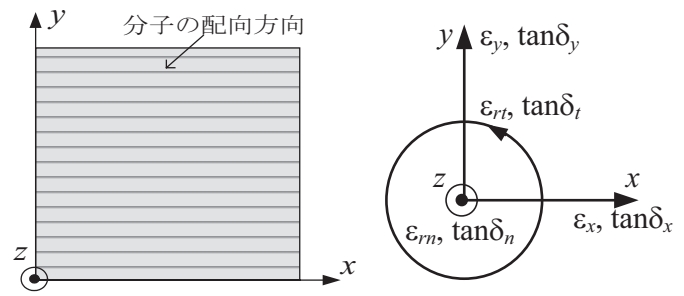

図 10. 誘電体基板の複素比誘電率の異方性 

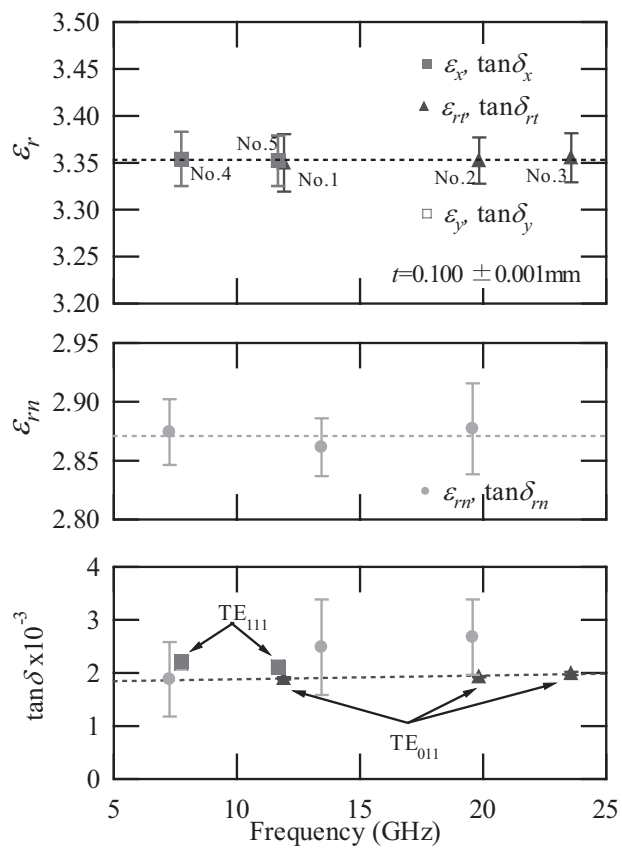

図 11. 改質 LCP フィルム (CT-Z) の測定結果
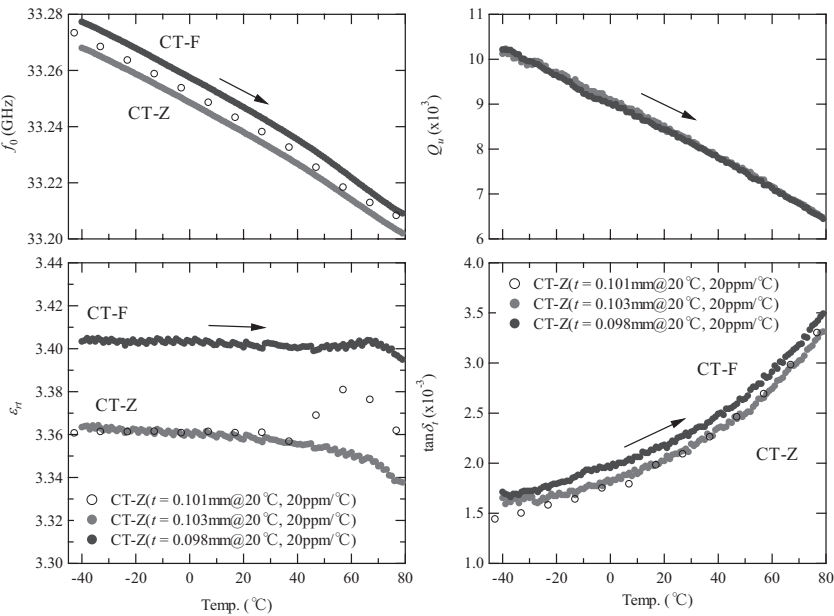

図 12. 2 種類の $L C P$ の $\varepsilon_{r t}, \tan \delta_{t}$ の温度依存性測定結果

を図 12 に示す ${ }^{20)}$ 。図中○印は最初の測定中, 温度上昇と 共に試料が伸びて空洞内でたわんだためとわかり, 以後の 測定では膜に重りをつけてぴんと張るようにした ${ }^{21)} 。 \varepsilon_{r n}$ は ともに温度依存性の少ない良好な特性が得られた。また $\tan \delta_{n}$ はともに同じ温度依存性を示した ${ }^{20), 21)}$ 。

\section{6 表面および界面比導電率の測定}

誘電体基板の両面には回路を形成するための銅箔が接着 される。従来より接着強度を上げるために基板と接する銅 䇴面は2 $5 \mu \mathrm{m}$ 面粗しされていた。マイクロ波・ミリ波帯 では表皮効果により電流は銅表面しか流れないため, 周波 数上昇とともに導体損が急激に上昇する。この影響を評価 するために標準軟銅の導電率 $58 \times 10^{6} \mathrm{~S} / \mathrm{m}$ に対する実効比 導電率を導入した。複数個の誘電体共振器を構成して測定 した種々の銅張基板の $\sigma_{r f}$ および $\sigma_{r b}$ の測定結果を図 13 に示
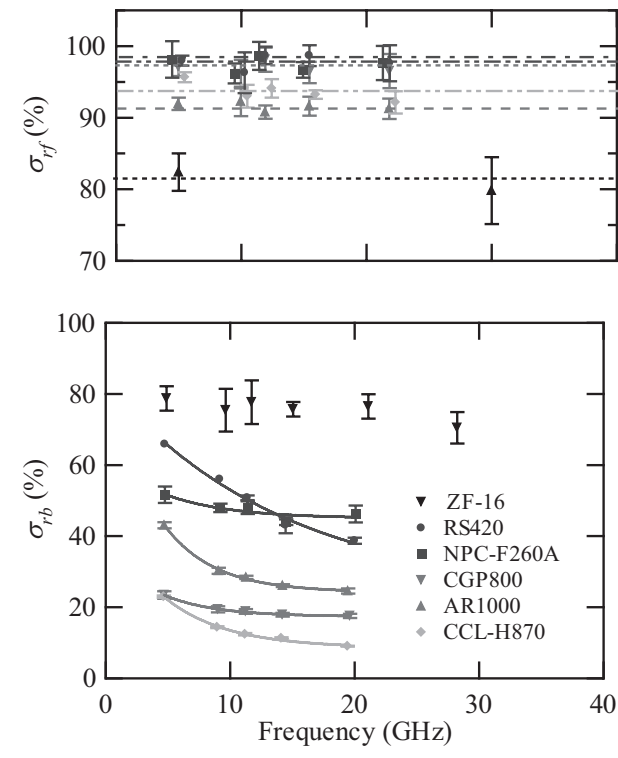

図 13. 表面および界面比導電率の測定結果

$す^{8)}$ 。特に ZF-16 基板表面への銅層形成は UV 照射による 表面改質後, 無電解銅めっきを $0.5 \mu \mathrm{m}$ 施し, さらに電界めっ きで $10 \mu \mathrm{m}$ の厚さの銅䈃層が形成されたものである ${ }^{22)}$ 。銅 張積層板に比べて，マイクロ波特性が良好であり，今後こ の種の銅䇴形成の開発が期待される。

\section{4. まとめ}

各種共振器法により測定された銅層形成誘電体基板につ いて，面方向・垂直方向複素比誘電率および銅䇴表面・界 面比導電率の測定結果を紹介した。これらの測定值を用い た電磁界解析ソフトの計算よりマイクロ波・ミリ波回路の 高精度設計が実現されれば，試作による検証過程を相当省 略できるものと期待する。またこれらの測定法は新基板材 料の開発にも有用である。

\section{謝 辞}

本研究で使用した測定装置の開発にご協力頂いた川島製 作所の赤坂清三氏に深甚の謝意を表します。

(2015.6.25- 受理)

\section{文献}

1) 吉冨了平, 小林禧夫, 馬哲旺 : “銅張り誘電体積層基板に関 する材料定数の測定結果を用いたマイクロストリップ線路 の伝搬定数の高精度評価,”エレクトロニクス実装学会誌,

Vol. 14, No. 2, pp. 114-120, Mar. 2011

2) 相羽 英, 小林禧夫, 馬哲旺 : “誘電体積層基板の一軸異方 性を考慮したマイクロ波フィル夕設計に関する検討,”信学 論 (C), Vol. J91-C, No. 12, pp. 728-735, Dec. 2008

3) Y. Kobayashi: "Microwave characterization of copper-clad dielectric laminate substrates," IEICE Trans. ELECTRON., Vol. E90-C, No. 12, pp. 2178-2184, Dec. 2007 
4）小林禧夫：“銅張り誘電体積層基板のマイクロ波評価技術, ” 信学論 (C), Vol. J89-C, No. 5, May 2006

5) 蓮池健一, 川端広一, 小林禧夫：“マイクロ波帯における誘 電体基板の一軸異方性複素誘電率の周波数依存性測定, ”信 学論 (C), Vol. J89-C, No. 12, pp. 1039-1046, Dec. 2006

6) 小林禧夫, 蓮池健一：“実装回路用誘電体基板のマイクロ 波・ミリ波評価,”エレクトロニクス実装学会 超高速高周 波エレクトロニクス実装研究会, 平成 18 年度第 3 回公開研 究会論文集, Vol. 6, No. 3, pp. 23-28, Nov. 2006

7) 中井 宏, 小林禧夫, 吉冨了平, 馬哲旺: “銅張り有機材料 基板の複素誘電率及び導電率のマイクロ波特性, ” エレクト ロニクス実装学会 超高速高周波エレクトロニクス実装研 究会 平成 20 年度第 2 回公開研究会論文集, Vol. 8, No. 2, pp. 1-6, Aug. 2008

8) 小林禧夫：“銅張りプリント配線基板のマイクロ波・ミリ波 特性と実測例, ” RF ワールド, No. 12, pp. 57-69, Nov. 1, 2010, CQ 出版社

9) 小林禧夫, 吉冨了平, 馬哲旺 : “銅層形成シクロオレフィン ポリマー基板のマイクロ波特性評価,”エレクトロニクス実 装学会 超高速高周波エレクトロニクス実装研究会 平成 21 年度第 3 回公開研究会論文集 Vol. 9, No. 3, pp. 1-4, Nov. 6, 2009

10) H. Kawabata, K. Hasuike, Y. Kobayashi, and Z. Ma: "Multifrequency measurement of complex permittivity of dielectric plates using higher-order modes of a balanced-type circular disk resonator," Proc. 36th European Microwave Conf., pp. 388-391, Sep. $10-15,2006$

11) 清水隆志, 小林禧夫, 馬哲旺 : “同軸励振円板共振器法によ る誘電体基板の複素誘電率温度依存性測定, ”2007 年 電子 情報通信学会ソサエティ大会, C-2-79, Sep. 2007

12）宮澤慎介：“情報機器の進化に貢献する素材“シクロオレ フィンポリマー”,”エレクトロニクス実装学会誌, Vol. 16, No. 5, pp. 394-398, Aug. 2013

13) H. Kanno, H. Ogura, and K. Takahashi: "Surface mountable liquid crystal polymer Package with vertical via transition compensating wire inductance up to V-vand," IEEE MTT-S nt. Microwave Symp. Dig., pp. 1156-1162, June 2003

14) D. C. Thompson, O. Tantot, H Jallageas, et al.: "Characterization of liquid crystal polymer (LCP) material and transmission lines on LCP substrates from 30 to $110 \mathrm{GHz}$," IEEE Trans. Microwave Theory Tech., Vol. 52, pp. 1343-1352, Apr. 2004

15) S. Wadayama, Y. Kobayashi, and Z. Ma: "Discussions on microwave measurement of permittivity anisotropy in the plane of dielectric laminate substrates," Proc. 2010 Asia-Pacific Microwave Conf. (APMC2010), FR3C-3, pp. 1773-1776, Dec. $7-10,2010$

16）和田山修平，小林禧夫，馬哲旺：“誘電体積層基板の複素誘 電率の面内異方性の周波数依存性測定,”第 25 回エレクト ロニクス実装学春季講演大会講演論文集，10E-01, Mar. 10, 2011

17）和田山修平，小林禧夫，馬哲旺：“液晶ポリマーフィルムの 複素誘電率の異方性改善の評価, ”エレクトロニクス実装学 会 超高速高周波エレクトロニクス実装研究会平成 23 年 度第 3 回公開研究会論文集, Vol. 11, No. 3, pp. 21-26, Nov. 4, 2011

18）小野寺，砂本，小林：“回路基材としての液晶ポリマーフィ ルムの誘電特性改善,”第 26 回エレクトロニクス実装学会 春季講演大会, 8A-02, pp. 51-52, Mar. 2012

19）金子彰吾，小林禧夫，馬哲旺：“平衡形円板共振器法による $110 \mathrm{GHz}$ にわたる誘電体基板の複素誘電率測定,”2011 年電 子情報通信学会総合大会, C-2-50, Mar. 14 17, 2011

20）金子彰吾，小林禧夫，馬哲旺：“平衡形円板共振器を用いた 有機基板の複素誘電率の温度依存性測定,”2011 信学ソ大 会, C-2-76, Sept. 2011

21）常光理志，小林禧夫，小野寺 稔：“液晶ポリマーフィルム の複素比誘電率の温度依存性測定, ”第 27 回エレクトロニ クス実装学春季講演大会講演論文集, 15C-01, Mar. 5, 2013

22）渡辺充広, 松井貴一, 杉本将治, 本間英夫 : “シクロオレ フィンポリマーヘの平滑回路形成,”エレクトロニクス実装 学会誌, Vol. 10, No. 3, pp. 229-233, May 2007

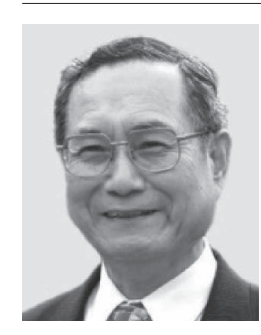

小林禧夫（こばやし よしお） 著者紹介 2005 年 3 月 埼玉大学工学部定年退職 埼玉大学名誉教授。工学博士。 2004 年 7 月サムテック有限会社創業, 現在代表取締役 電子情報通信学会フェロー IEEE Life Fellow 